\title{
POLA PERESEPAN PENGGUNAAN OBAT DEMAM TIFOID DI INSTALASI RAWAT INAP RS BHINEKA BAKTI HUSADA
}

\author{
Neneng Sri Purwaningsih, Alfian Nita \\ Sekolah Tinggi Ilmu Kesehatan Kharisma Persada \\ Tangerang Selatan, 15417, Indonesia \\ E-mail: neneng.masda@ac.id
}

\begin{abstract}
ABSTRAK
Demam tifoid merupakan penyakit infeksi yang disebabkan oleh bakteri Salmonella typhi. Sampai dengan saat ini demam tifoid masih menjadi masalah kesehatan di negara- negara tropis termasuk Indonesia. Antibiotik merupakan obat utama yang digunakan untuk mengobati penyakit demam tifoid. Penelitian ini dilakukan dengan metode observasi dan bersifat deskriptif dengan pengambilan data secara retrospektif yang artinya melihat data ke belakang dengan melihat data rekam medis periode Januari-Desember 2018. Pengambilan sampel menggunakan total sampling yaitu sebanyak 69 orang pasien demam tifoid di Instalasi Rawat Inap Rumah Sakit Bhineka Bakti Husada. Dari hasil penelitian menunjukkan bahwa peresepan obat demam tifoid di Rumah Sakit Bhineka adalah antibiotik dan antipiretik yaitu sebanyak 69 kasus (100\%), umur pasien Demam Tifoid adalah usia 2-12 tahun sebanyak 46 orang $(66,66 \%)$, dan untuk jenis kelamin pasien Demam Tifoid adalah laki-laki sebanyak 41 orang $(59,43 \%)$. Obat yang paling sering di resepkan untuk pasien Demam Tifoid adalah golongan Sefalosporin injeksi $(91,30 \%)$ dan Anti Piretik berupa Parasetemol tablet dan sirup $(100 \%)$.
\end{abstract}

Kata Kunci : Demam tifoid, antibiotik, antipiretik, ceftriaxone injeksi, parasetamol

\begin{abstract}
Typhoid fever is an infectious disease caused by Salmonella typhi bacteria. Until now typhoid fever is still a health problem in tropical countries including Indonesia. Antibiotics are the main drugs used to treat typhoid fever. This research was conducted with observational and descriptive methods by taking data retrospectively, which means looking back at the data by looking at the medical record data for the JanuaryDecember 2018 period. Sampling used a total sampling of 69 patients in the inpatient installation at Bhineka Hospital. Bakti Husada. The results showed that prescribing typhoid fever drugs at Bhineka Hospital were antibiotics and antipyretics as many as 69 cases (100\%), the age of typhoid fever patients was 2-12 years old as many as 46 people (66.66\%), and for the sex of the patient Typhoid fever is male as many as 41 people (59.43\%). The drugs most often prescribed for typhoid fever patients are cephalosporins in the form of Ceftriaxone injection (91.30\%) and antypyretics is a tablets of Paracetemol and syrup (100\%).
\end{abstract}

Keywords : Thypoid fever, antibiotics, antipyretics, Ceftriaxone injection, Paracetemol 


\section{PENDAHULUAN}

Demam tifoid adalah infeksi sistemik yang disebabkan oleh Salmonella typhi, biasanya melalui konsumsi makanan atau air yang terkontaminasi (WHO, 2011).Hingga saat ini penyakit demam tifoid masih merupakan masalah kesehatan di negara-negara berkembang terutama negara-negara dengan sanitasi yang rendah termasuk Indonesia. Menurut riset Kesehatan Dasar (RISKESDAS) pada tahun 2007 prevalensi demam tifoid mencapai $1,6 \%$ di tahun 2010 demam tifoid masih menduduki peringkat tiga dari 10 penyakit terbanyak di Indonesia (Kemenkes, 2010).

Dalam penggunannya, antibiotik berbeda dengan penggunaan jenis obatobatan yang lainnya, selain harus memperhatikan pasien dan obat kita juga harus memperhatikan karateristik dari infeksi yang akan ditangani. Penggunaan obat pada anak-anak tidak seperti pada orang dewasa pada umumnya, mengingat anak berbeda dengan orang dewasa.Demam tifoid yang disebabkan oleh Salmonella Typhi masih merupakan masalah kesehatan masyarakat di dunia khususnya di negara-negara sedang berkembang, termasuk Indonesia.WHO memperkirakan terdapat 17 juta kasus demam tifoid di seluruh dunia dengan insiden 600.000 kasus kematian tiap tahun. Di Indonesia, tifoid harus mendapat perhatian serius dari berbagai pihak, karena penyakit ini bersifat edemis dan mengancam kesehatan masyarakat. Permaslahannya semakin kompleks dengan meningkatnya kasus-kasus karier atau relapsdan resistensi terhadap obatobat yang dipakai, sehingga menyulitkan upaya pengobatan dan pencegahan. Menurut data World Health Organization (WHO) angka penderita demam tifoid di Indonesia mencapai $81 \%$ per 100.000 populasi pertahun. Berdasarkan laporan Ditjen Pelayanan Medis Departemen Keshetan RI tahun 2013, demam tifoid menempati urutan ke 2 dari 10 penyakit terbanyak pasien rawat inap di Rumah Sakit di Indonesia dengan jumlah kasus 81.116 dengan prevalensi 3,15\% (Depkes RI, 2009). Prevalensi tifoid banyak ditemukan pada kelompok usia 5-14 tahun yaitu (1,9\%). Usia 1-4 tahun $(1,6 \%)$, usia $15-24$ tahun $(1,5 \%)$ dan usia $<1$ tahun $(0,8 \%)$ (Depkes RI, 2013). 


\section{METODE}

Penelitian ini merupakan penelitian deskriptif dengan pengambilan data secara retrospektif. Tujuan penelitian ini adalah untuk mengetahui profil pola peresepan penggunaan obat demam tifoid pada pasien rawat inap di RS Bhineka Bakti Husada periode Januari - Desember tahun 2018.

$$
\text { Pengambilan sampel yang }
$$
digunakan dalam penelitian ini adalah dengan Total Sampling yaitu teknik pengambilan sampel dimana jumlah sampel sama dengan populasi yang di ambil. (Notoatmodjo, 2010).

Proses pengumpulan data pada penelitian ini adalah dengan mengumpulkan data rekam medis pasien Demam Tifoid Instalasi Rawat Jalan
Rumah Sakit Bhineka Bakti Husada periode Januari - Desember 2018.

Instrumen yang digunakan dalam penelitian ini yaitu lembar observasi atau lembar ceklis pasien demam tifoid di instalasi rawat jalan Rumah Sakit Bhineka Bakti Husada yang meliputi : usia, jenis kelamin, golongan obat, nama obat, bentuk sediaan.

Proses analisis data pada penelitian ini dilakukan dengan analisis secara univariat yaitu dengan cara analisis distribusi frekuensi dengan rumus : ( Setiadi, 2007)

$\mathrm{P}=\mathrm{F} / \mathrm{N} \times 100 \%$

Keterangan :

$\mathrm{P}=$ Presentase $(\%)$

$\mathrm{F}=$ Frekuensi

$\mathrm{N}=$ Sampel

\section{HASIL}

\section{Karakteristik Pasien}

a. Kriteria Berdasarkan Usia

Tabel 1. Karakteristik Berdasarkan Usia Pasien Demam Tifoid

\begin{tabular}{lcc}
\hline \multicolumn{1}{c}{ Rentang Usia } & Jumlah & $\%$ \\
\hline $0-1$ bulan & 0 & 0 \\
2bulan-2 tahun & 12 & 17,40 \\
3-12 tahun & 46 & 66,66 \\
13-18 tahun & 2 & 2,90 \\
19-65 tahun & 8 & 11,60 \\
$>65$ tahun & 1 & 1,44 \\
\hline \multicolumn{1}{c}{ Total } & 69 & 100
\end{tabular}

Sumber : Rekam Medis Pasien Tifoid di Instalasi Rawat Jalan RS Bhineka Bakti Husada Periode Januari- Desember 2018 
Berdasarkan tabel 1 rentang usia pasien tifoid yang paling banyak pada usia 2 - 12 tahun sebanyak 46 kasus $(66,66 \%)$ urutan rentang usia kedua pada usia 1 bulan - 2 tahun sebanyak 12 kasus $(17,40 \%)$ urutan rentang usia ketiga pada usia 18 - 65 tahunsebanyak 8 kasus $(11,60 \%)$ urutan rentang usia keempat pada usia 12 - 18 sebanyak 2 kasus $(2,90 \%)$ urutan rentang usia $>65$ tahun sebanyak 1 kasus $(1,44 \%)$.

b. Kriteria Berdasarkan Jenis Kelamin

Tabel 2. Demografi Pasien Tifoid Brdasarkan Jenis Kelamin

\begin{tabular}{ccc}
\hline Jenis Kelamin & Jumlah & \% \\
\hline Laki-laki & 41 & 59,43 \\
Perempuan & 28 & 40,57 \\
\hline Total & 69 & 100 \\
\hline
\end{tabular}

Sumber : Rekam Medis Pasien Tifoid di Instalasi Rawat Jalan RS Bhineka Bakti Husada Periode Januari- Desember 2018

Berdasarkan Tabel 2 menunjukkan bahwa tifoid di RS Bhinneka Bakti Husada pada tahun 2018 jenis kelamin yang paling banyak terkena demam tifoid adalah laki-laki berjumlah 41 kasus $(59,43 \%)$ dan perempuan 28 kasus $(40,57 \%)$

\section{Pola Peresepan Obat}

a. Kriteria berdasarkan Jenis Obat Antibiotik

Tabel 3. Berdasarkan Jenis Obat Antibiotik

\begin{tabular}{|c|c|c|}
\hline Jenis Obat Antibiotik & $\begin{array}{c}\text { Jumlah } \\
\text { pasien }\end{array}$ & $\%$ \\
\hline Penisilin & 0 & 0 \\
\hline Sefalosporin & 63 & 91,30 \\
\hline Kloramfenikol & 6 & 8,70 \\
\hline Tetrasiklin & 0 & 0 \\
\hline Eritromisin & 0 & 0 \\
\hline Azitromisin & 0 & 0 \\
\hline Klaritromisin & 0 & 0 \\
\hline Klindamisin & 0 & 0 \\
\hline Mupirosin & 0 & 0 \\
\hline Trimetrohoprim & 0 & 0 \\
\hline Total & 69 & $100 \%$ \\
\hline
\end{tabular}

Sumber : Rekam Medis Pasien Tifoid di Instalasi Rawat Jalan RS Bhineka Bakti Husada Periode Januari- Desember 2018 
Tabel 4. Berdasarkan Jenis Obat Antipiretik

\begin{tabular}{lcc}
\hline Jenis Obat & Jumlah pasien & $\%$ \\
Antipiretik & 69 & 100 \\
\hline Paracetamol & 0 & 0 \\
Ibuprofen & 69 & $100 \%$ \\
\hline \multicolumn{1}{c}{ Total } & 9
\end{tabular}

Sumber : Rekam Medis Pasien Tifoid di Instalasi Rawat Jalan RS Bhineka Bakti Husada Periode Januari- Desember 2018

b. Kriteria berdasarkan bentuk sediaan obat

Tabel 5. Berdasarkan Bentuk Sediaan Obat Antibiotik

\begin{tabular}{|c|c|c|}
\hline Bentuk sediaan & Jumlah pasien & $\%$ \\
\hline Injeksi & 69 & 100 \\
\hline Sirup & 0 & 0 \\
\hline Tablet & 0 & 0 \\
\hline Kapsul & 0 & 0 \\
\hline
\end{tabular}

Sumber : Rekam Medis Pasien Tifoid di Instalasi Rawat Jalan RS Bhineka Bakti Husada Periode Januari- Desember 2018

Tabel 6. Berdasarkan Bentuk Sediaan Obat Antipiretik

\begin{tabular}{lcc}
\hline \multicolumn{1}{c}{ Bentuk sediaan } & Jumlah pasien & $\mathbf{\%}$ \\
\hline Injeksi & 0 & 0 \\
Sirup & 40 & 57,98 \\
Tablet & 29 & 42,02 \\
Kapsul & 0 & 0 \\
Suppositoria & 0 & 0 \\
\hline Total & 69 & $100 \%$ \\
Sumber : Rekam Medis Pasien Tifoid di Instalasi Rawat Jalan RS Bhineka Bakti &
\end{tabular}

\section{DISKUSI}

1. Karakteristik Pasien

a. Berdasarkan Usia

Berdasarkan hasil penelitian

yang telah penulis lakukan

dapat diketahui bahwa obat

yang diresepkan oleh dokter

pada pasien demam tifoid di

rawat inap RS Bhineka Bakti

Husada dikelompokkan berdasarkan usia, yang bertujuan untuk mengetahui rentang usia pada pasien demam tifoid menunjukkan bahwa dari 69 pasien demam tifoid yang paling banyak pada rentang usia $2-12$ tahun dengan presentase $(66,66 \%)$ dan paling sedikit rentang usia 
$>65$ tahun dengan presentase

$(1,44 \%)$

Hasil ini sesuai prevalensi

tifoid yang paling tinggi

menurut Dinas Kesehatan

(2009) pada usia 5-14 tahun

karena pada usia sekolah

tersebut

kurang

memperhatikan

pola

makannya dan mereka lebih

cenderung untuk memilih

makanan yang ada di luar

rumah dan kurang hygienis.

b. Berdasarkan Jenis Kelamin

Hasil yang didapatkan

bahwa jumlah pasien laki-laki

paling banyak terdiagnosis

demam tifoid dengan

presentase

(59,43\%)dibandingkan

perempuan dengan presentase $(40,57 \%)$.

Hasil ini sesuai dengan

pustaka bahwa anak yang terdiagnosis menderita demam tifoid lebih banyak terjadi pada jenis kelamin laki-laki dibandingan dengan jenis kelamin perempuan. Hal ini disebabkan laki-laki lebih banyak bermain di luar rumah dan sering jajan sembarangan dibandingkan dengan perempuan yang lebih menyukai didalam rumah sehingga tidak sering jajan sembarangan karena perempuan lebih memperhatikan kebersihan makanan yang akan dikonsumsi (Kemenkes RI, 2014).

2. Pola Peresepan

a. Bentuk Sediaan Obat Antibiotik

Bentuk sediaan yang paling banyak digunakan pada pasien demam tifoid di RS Bhineka Bakti Husada adalah injeksi. Hasil ini sesuai dengan pustaka BNF For Children (2012)

merekomendasikan

pengobatan demam tifoid dalam bentuk sediaan injeksi.Demam tifoid disebabkan oleh bakteri gram negatif Salmonella Typhi.Jika tidak diberikan secara injeksi bakteri yang ada di dalam tubuh pasien akan berkembangbiak secara cepat sehingga memperpanjang waktu penyembuhan. Pemberian obat secara injeksi pasien lebih terkontrol dan 
patuh minum obat secara teratur. (BNFFC, 2012).

b. Bentuk Sediaan Obat Antipiretik

Bentuk sediaan yang paling banyak digunakan pada pasien demam tifoid di RS Bhineka Bakti Husada adalah sirup. Hasil ini sesuai dengan pustaka BNF For Children

merekomendasikan

pengobatan demam tifoid dalam bentuk sediaan sirup. Demam tifoid disebabkan oleh bakteri gram negatif Salmonella Typhi (BNFFC, 2012).

c. Berdasarkan Jenis Obat Antibiotik

Berdasarkan jenis obat yang digunakan pasien demam tifoid yaitu golongan antibiotik sefalosforin sebanyak 69 kasus (100\%). Antibiotik adalah zat yang dihasilkan oleh mikroorganisme atau dihasilkan secara sintetik yang dapat membunuh atau menghambat perkembangan mikroorganisme, sehingga antibiotik akan membunuh atau menghambat Salmonella Typhi didalam tubuh manusia. Penggunaan sefalosporin yang lebih banyak dibandingkan dnegan penggunaan antibiotik lain, dikarenakan pasien demam tifoid di RS Bhineka Bakti Husada lebih besar adalah pasien BPJS dan sefalosporin adalah antibiotik yang diutamakan untuk demam tifoid pada pasien BPJS (Menkes, 2011).

d. Berdasarkan Jenis Obat Antipiretik

Berdasarkan jenis obat yang digunakan pasien demam tifoid yaitu golongan antipiretik paracetamol sebanyak 69 kasus (100\%). Antipiretik adalah obat penurun panas, obat-obat antipiretik juga menekan gejala-gejala yang biasanya menyertai demam mialgia, kedinginan, nyeri kepala, dan lain-lain.Demam tifoid berasal dari infeksi sistemik yang disebabkan oleh Salmonella Typhi. Penggunaan paracetamol lebih banyak karena paracetamol memiliki efek 


$\begin{array}{lll}\text { samping lebih } & \text { ringan } & \text { ibuprofen. (WHO, 2003). } \\ \text { dibandingkan } & \text { dengan }\end{array}$

\section{SIMPULAN}

Berdasarkan hasil penelitian mengenai pola peresepan penggunaan obat demam tifoid di instalasi rawat inap Rumah Sakit Bhineka Bakti Husada periode Januari- Desember 2018 dengan 69 sampel dapat disimpulkan: Usia paling banyak terserang penyakit demam tifoid adalah $2-12$ tahun sebanyak 46 kasus $(66,66 \%)$. Jenis kelamin paling

Bhutta ZA. 2013. Typhoid fever: current concepts. Infect Dis Clin Pract; $14 ; 266-72$.

BNF For children. 2012. The Essential Resource For Clinical use of Medicine in Children. Lambeth High Street, London, SEI 7JN, UK. Pharmaceutical Press.

Devi Nurvania. 2017. Pola Peresepan Obat Typoid Pada Pasien Anak Di Instalasi Rawat Inap RSU Kabupaten Tangerang.

Elbadiansyah, 2019. Manajemen sumber daya manusia dari URL; https:// books. Google, co.id / books. banyak laki-laki sebanyak 41 kasus $(59,43 \%)$. Bentuk sediaan yang diberikan antibiotik (Injeksi) sebanyak 69 kasus (100\%) dan antipiretik (Sirup) sebanyak 40 kasus $(42,02 \%)$. Jenis obat yang paling banyak diberikan antibiotik (Sefalosporin) sebanyak 63 kasus $(91,30 \%)$. Jenis obat yang paling banyak diberikan yaitu antipiretik (paracetamol) sebanyak 69 kasus (100\%).

\section{DAFTAR PUSTAKA}

Elmitra, 2017. Bentuk sediaan obat dari: URL; https:// books. Google. co.id / book.

Harmita dan Radji, M., 2008. Kepekaan Terhadap Antibiotik. Dalam: Buku Ajar Analisis Hayati. Eds 3. EGC. Jakarta.

Kemenkes RI, Pedoman pelayanan kefarmasian untuk terapi Antibiotik. Kementrian Kesehatan Republik Indonesia. Jakarta. 2013

Kemenkes RI, 2006. Pengendalian Demam Tifoid. Menteri Kesehatan Republik Indonesia : Jakarta. 
Kemenkes RI. 2009. Profil Kesehatan Indonesia.Jakarta:Kementrian Kesehatan RI Tahun 2009

Mareta Endra Wijaya, 2016 . "Gambaran Pemberian Antibiotik Pada Pasien Demam Tifoid Di Instalasi Rawat Inap RSUD Sleman Tahun 2015".

Notoadmodjo, $\quad$ Soekidjo. 2012. Metodologi Penelitian

Kesehatan. Jakarta: Rineka Cipta.

Notoatmodjo, S. 2010. Metodologi Penelitian Kesehatan. Rineka Cipta: Jakarta.

Prest, 2003. Penggunaan Obat Dalam: Farmasi Klinis, Editor: Aslam. Jakarta: PT Gramedia

Sevilla, Consuelo. G. et.al. 2007. Research Metods. Rexprinting Company. Quezon City.

SoedarmoSumarno SP, Gama Herry, Rezki Sri SH, dan Irawan HS, 2012. DemamTifoid. Dalam: Buku Ajar InfeksidanPediatriTropis. Edisi ke 2. Jakarta: Ikatan Dokter Indonesia. h.338-345.

Soedarmo, et al. 2008. Buku Ajar Infeksidan pediatric tropis.Badan Penebit IDAI : Jakarta.

Sudoyo,AW, 2008. Buku Ajar Ilmu Penyakit Dalam Jilid 3, Fakultas Kedokteran Universitas Indonesia: Jakarta.

Surgery in Africa-Monthly Review. Tyipoid Fever. Diaskes dari: URL;

http://www.prolemy.ca/members /archives/2006/typoid_fever.htm Tanggal 30 Maret 2018

Supriyono, 2011. Buku Demam Tifoid Dalam, Pusat Penerbitan Penyakit Dalam: Jakarta.

Rampengan, 2008. Demam Tifoid Dalam, Edisi ke 2 Jakarta: EGC;

Tjay, H.T. \& Rahardja, K., 2007. Obatobat penting, Khasiat, Penggunaannya, Efek samping, Edisi ke V, Catatan ke-2. PT Elex Media Komputindo: Jakarta. 